Раскрытие социально-психологических механизмов функционирования имиджа, их учет и использование необходимы для развития продуктивной деятельности по формированию оптимального имиджа как феномена межличностного взаимодействия.

Ключевые слова: имидж современного лидера, имидж как феномен межличностного взаимодействия, социально-психологические механизмы функционирования имиджа, Я-концепция лидера, деятельность по созданию имиджа лидера.

O. Turynina, Doctor habilitatus in Psychology, PhD., Prof.

Interregional Academy of Personnel Management, Kyiv

A. llyanova, Doctor habilitatus in Psychology, PhD.

Kyiv

\title{
SOCIAL AND PSYCHOLOGICAL MECHANISMS OF FUNCTIONING THE IMAGE OF A MODERN LEADER IN THE CONDITIONS OF THE MODERN STAGE OF DEVELOPMENT OF THE UKRAINIAN SOCIETY
}

The work is devoted to the psychological analysis of the features of the image of the leader at the present stage of development of the Ukrainian state. The need for psychological studies of the image is conditioned by the contradictions between the social practice of image functioning in different spheres of social life and the need for its theoretical reflection. Methods based on the means of social and psychological influence become significant. Among these tools, the image of the leader is essential. During the creation of his vision, the leader demonstrates the most attractive individual, personal, and professional qualities, learns to see them in themselves "from the side", is aware of his shortcomings, correlates his own characteristics with the standard of personality. In recent years, the concept of the image has firmly entered the information space. In most cases, the image is perceived by people like a specific value, which is associated with the success of certain activities, both individual and collective. Representatives of psychological science have increased their interest in the phenomenon of an image, as evidenced by the sharp increase in recent years in the number of scientific publications on topics related to the image or its aspects. As a result of research using the methods of a questionnaire survey followed by in-depth interviews in focus groups, the ranking structure of the expert model of an ideal modern leader and the ranking structure of the image model of a modern leader in everyday consciousness are presented. The findings of the study described the socio-psychological mechanisms of the functioning of the image as a phenomenon of interpersonal interaction, including: the manifestation of the characteristics of group interaction; the use of social representations and stereotypes; the realization of the self-concept of the subject of the image in correlation relationships with the self-concepts of other subjects of image interaction and the like. The disclosure of the socio-psychological mechanisms of the functioning of the image, their accounting and use are necessary for the development of productive activities on the formation of an optimal image as a phenomenon of interpersonal interaction.

Keywords: image of a modern leader, image as a phenomenon of interpersonal interaction, social and psychological mechanisms of image functioning, self-concept of a leader, activity on creating an image of a leader.

Bulletin of Taras Shevchenko National University of Kyiv.

Series "Psychology". № 2(9), pp. 84-87 (2018)

УДК 159.9.316

DOI: https://doi.org/10.17721/BSP.2018.2(9).21
ISSN $1728-3817$

(C) Taras Shevchenko National University of Kyiv,

Publishing Center "Kyiv University", 2018

Г. Халєєва, асп. Київський національний університет імені Тараса Шевченка, Київ

\section{АНАЛІЗ ОСНОВНИХ ПІДХОДІВ ДО ТРАКТУВАННЯ СУБ'ЄКТИВНОГО БЛАГОПОЛУЧЧЯ В ПСИХОЛОГІї}

Проаналізовано основні теорії суб'єктивного благополуччя. Показано основні розбіжності між теоріями, а також взаємозв'язок понять "суб'єктивне благополуччя" та "психологічне благополуччя". Охарактеризовано основні підходи щодо з'ясування складових суб'єктивного благополуччя.

Ключові слова: суб'єктивне благополуччя, щастя, задоволеність життям, психологічне благополуччя, якість життя.

Вступ. На сьогодні актуально для збереження та відновлення психологічного й фрізичного здоров'я усвідомити те, що саме лежить в основі благополуччя. Будучи явищем індивідуального буття людини воно не $є$ найбільш чітко усвідомленим. Що саме має на увазі людина, коли вважає себе благополучною чи неблагополучною?

На сьогодні немає чіткого, загального та універсального визначення суб'єктивного благополуччя як явища, незважаючи на те, що ця проблема пов'язана з усіма ссрерами людської життєдіяльності - особистісною, соціальною, професійною, економічною, фізичною, ціннісною, сімейною та багатьма іншими і $є$ предметом обговорення представників різних галузей наукових знань.

Оскільки прагнення до благополуччя $є$ однією з основних рушійних сил людського суспільства, його суб'єктивне відчуття $\epsilon$ важливою умовою повноцінного життя особистості, тому необхідними в психологічних дослідженнях залишаються питання, пов'язані з аналізом методологічних і системних підходів спрямованих на вивчення суб'єктивного благополуччя.

Аналіз останніх досліджень. Ряд теоретичних і практичних досліджень присвячені зв'язку суб'єктивного благополуччя й соціального статусу (Zaidi et al., 2009; Larson, 1978), освіти (M. Pinquart, S. Sorensen, 2000; A. Cid et al., 2007; T. Kudo et al., 2007; R. Fernandez, J. Kulik, 1981), віком (R. Larson, M. Csikszentmihalyi, 1978; D. Myers, E. Diener, 1995; E. Diener et al., 2009, E. Miller, 2013; K. Dolan et al., 2008; R. Fernandez, J. Kulik, 1981;
S.-L. Chen, 2001; W. Gwozdz, A. Sousa-Poza, 2009; D. Mroczek, A. Spiro, 2005; A. Steptoe et al., 2012).

Мета дослідження - здійснити теоретичний аналіз існуючих сучасних підходів до проблеми вивчення суб'єктивного благополуччя та його складових.

Виклад основного матеріалу дослідження. Вивчення проблеми суб'єктивного благополуччя відбувається сьогодні, як зазначено в дослідженнях, у межах двох підходів - гедоністичного і евдемоністичного.

При цьому гедонія в психологічних термінах характеризується як позитивний афект або задоволення, а евдемонія по суті означає переживання життя як повноцінного, значущого, привабливого. У публікаціях описуються результати емпіричних досліджень, які підтверджують тезу про те, що реальне благополуччя включає в себе обидва цих компонента (K. Berridge, 2011; V. Huta, R. Ryan, 2010). Таким чином, людина, яка вважає себе щасливою, із великою ймовірністю вказує на відчуття наповненості життя позитивними цілями та змістом (K. Berridge, 2011), а поєднання гедонічного й евдемонічного благополуччя корелює з більш високим рівнем суб'єктивного благополуччя (V. Huta; R. Ryan, 2010).

Відповідно до "Керівництва з вимірювання суб'єктивного благополуччя", опублікованому Організацією економічного співробітництва та розвитку (ОЕCP), необхідно розрізняти термін "суб'єктивне благополуччя" і більш широкий термін "благополуччя", який включає в себе як суб'єктивний компонент, так і об'єктивні чинники, такі, як дохід, житло, навколишнє середовище, здоров'я, освіту і 
т. п. (OECD, 2013). Diener уважав оцінку людиною свого власного життя відмінністю поняття "суб'єктивного благополуччя" (SWB), використовуючи термін "щастя" як синонім SWB (E. Diener, 2000). Дослідження виявили два аспекти суб'єктивного благополуччя: афективний компонент, який зазвичай ділиться на приємний афект і неприємний афект (E. Diener, 1990; E. Diener, R. Emmons, 1984) і когнітивний компонент, який називається "задоволеність" (F. Andrews, S. Withey, 1976).

Згідно із зарубіжним дослідженням, щасливі люди більш товариські, альтруїстичні, активні, подобаються собі, а так само відчувають симпатію до інших людей. Такі люди мають міцніше тіло і сильну імунну систему, більш розвинені навички вирішення конфліктних ситуацій, більш низькі показники дистреса і менше симптомів психічних розладів (D. Kahneman, A. Krueger, 2006; M. Eid, R. Larsen, 2008; A. Bergsma, R. Veenhoven, 2011; H. Winefieldet al., 2012). Задоволеність життям $€$ одним із ключових критеріїв життєздатності людини (Е. Рильська, 2013); позитивні емоції сприяють процесу адаптації до стресових ситуацій (О. Зотова, 2015; O. Zotova, L. Karapetyan, 2015), підтримки сталого психосоматичного здоров'я (А. Сірих та ін., 2011).

На сьогодні в науці використовується кілька понять, які тією чи іншою мірою відображають стан людини як "благополуччя". Л. Карапетян ототожнює суб'єктивне відчуття щастя і загальне задоволення життям із поняттям "психологічне благополуччя". Далі уточнює, що суб'єктивне благополуччя, як інтегративне, особливо значуще переживання, надає постійний вплив на різні параметри психічного стану людини i, як наслідок, на успішність поведінки, продуктивність діяльності, ефективність міжособистісної взаємодії. (Л. Карапетян, 2014).

Думки науковців щодо співвідношення понять "суб'єктивне благополуччя" і "психологічне благополуччя" також різняться. Так, Е. Діннер уважав, що суб'єктивне благополуччя є частиною психологічного благополуччя, на відміну від Н. Бредберна, за яким ці поняття $\epsilon$ взагалі тотожними. Сучасні дослідження також не мають чіткої та однозначної відповіді на це питання, тому можна зустріти різні варіанти, серед яких навіть такий, де психологічне є частиною суб'єктивного благополуччя.

Аналіз літературних джерел показав, що перші дослідження суб'єктивного благополуччя в сучасній психології виникли на основі ідей про позитивне фрункціонування особистості в рамках дослідження різних психологічних шкіл: гуманістичної теорії А. Маслоу, теорії індивідуальності К. Юнга, диспозиційної теорії особистості Г. Олпорта, ідеї повноцінного функціонування особистості К. Роджерса; теорія діяльності Рубінштейна - Леонтєва; система суспільних відносин людини В. Мясищева; система людинознавства Б. Ананьєва. Теоретичну базу для вивчення феномена суб'єктивного благополуччя як окремого поняття заклали ідеї дослідження психічного здоров'я М. Ягоди; праці з дослідження динаміки суспільної думки для фрормування масової свідомості та поведінки за допомогою мас медіа X. Кентріла та основні класичні підходи до розуміння суб'єктивного благополуччя в зарубіжній літературі, які представлені в теоріях:

1. Теорія E. Diener, яка була концептуалізована як конструкт, що складається із двох основних компонентів: афективного (або емоційного) і суб'єктивного (або когнітивного) (E. Diener, 1984; Veenhoven, 1984). Причому їх взаємозв'язок не має прямої залежності в суб'єктивних переживаннях, вони $€$ незалежними компонентами благополуччя. На думку E. Diener, суб'єктивне благополуччя відображає оцінку людиною свого життя і включає в себе позитивні емоції, задоволеність життям і відносну відсутність негативних емоцій та настроїв. Використовуючи термін "щастя" як синонім суб'єктивному благополуччю, ним були виділені різні рівні оцінки життя: рівень загальної задоволеності життям, рівень задоволеності окремими сферами життєдіяльності (шлюбом, навчанням, роботою) і рівень емоційної задоволеності. Уперше вимір якості життя застосовувався в соціологічних дослідженнях (Andrews \& Withey, 1976), пізніше E. Diener концептуалізує його як суб'єктивний компонент задоволення життям (E. Diener, R. Emmnos, R. Larsen, S. Griffin, 1985). Як позитивні, так і негативні оцінки, містять судження й почуття про задоволеність життям, зацікавленості та залучення, афективні реакції, такі, як радість і смуток життєвих подій, задоволення роботою, відносинами, здоров'ям, відпочинком, сенсом і метою та інші важливі соери. Однак важливо зазначити, що хоча благополуччя суб'єктивно сприймається в досвіді людини, вияви суб'єктивного благополуччя можуть об'єктивно вимірюватися вербально і невербально - у поведінці, увазі й пам'яті (Subjective WellBeing: A General Overview Ed Diener, Katherine Ryan First Published December 1, 2009; pp. 391-406).

2. Згідно з теоріями адаптації, тривалий приємний досвід служить суттєвим фоном порівняння з іншими позитивним переживаннями, роблячи їх менш приємними (E. Diener, 2000), що призводить до появи потреб в отриманні все більш сильних вражень.

3. У контексті теорії соціал-дарвінізму вчені виявили прямі та зворотні зв'язки між зміною демографічних характеристик населення (щільність, половікова структура, міграція, географічний розподіл) і благополуччям, коли зміни в добробуті популяції, імовірно, приведуть до змін у демографрічних характеристиках населення (Frank M. Andrews, 1981).

4. Водночас, А. Маслоу вважав, що ядро характеру людини становлять позитивні, здорові, конструктивні імпульси, які починають діяти із самого народження. Із цього випливає, що теорія особистості, саме прагнення до розвитку, до особистісного зростання, тобто до само актуалізації, є основою розвитку і людини, і суспільства. У цілому, особливості суб'єктивного благополуччя можуть бути використані для розвитку цілісної особистості в контексті гуманістичних орієнтирів сучасності.

Термін "суб'єктивне благополуччя" є міждисциплінарним і має своє значення в психології, соціології, економіці та політичних науках.

Відповідно до теорії відносин В. Мясищева, ставлення людини - це потенціал, який свідомо виявляється в активній вибірковості переживань і вчинків, заснований на індивідуальному й соціальному досвіді.

Будучи соціально-психологічною характеристикою особистості, суб'єктивне благополуччя містить емоційно-оціночні ставлення людини до самої себе, соціальної дійсності і в цій якості визначає спрямованість її поведінки (Р. Шаміонов, 2004).

Синонімічними поняттю "суб'єктивного благополуччя" є часто вживані терміни "якість життя" (L. Camfild, S. Skevington, 2008), "щастя" (M. Stones, A. Kozma, 1989), "щастя та процвітання" (J. Vitterso, 2004; E. Diener, 2005; E. Diener, E. Sandvik, W. Pavot, 1991).

Виявлено економічні (В. Хащенко, 2012; E. Diener, 2000; Biswas-Diener, 2002), політичні (D. Canache, J. Mondak, M. Seligson, 2001), соціальні (Р. Шаміонов 2008, Л. Куликов, 1997), індивідуальні (P. Costa, Mc. Crae 1980; A. Tellegen 1985; B. Headey, A. Wearing 1992; D. Watson, L. Clark 1992) та етнокультурні (R. Chang, E. Chang, 2009; R. Inglehart, Klingemann 2000; R. Veenhoven 1993; E. Diener, S. Oishi, R. Lucas, 2002) детермінанти й етнопсихологічні (V. Chirkov, R. Ryan, C. Willness, 2005; H. Trandis, 2000) аспекти суб'єктивного благополуччя, визначені ступінь і критерії оцінок.

Дж. Стігліца, А. Сена і Ж.-П. Фітусі в контексті економічного розвитку й соціального прогресу представили Індекс благополуччя (ІБ-2011), який поєднує статистич- 
ні дані, результати соціологічних опитувань і експертні оцінки (Г. Балашова, 2012).

Зафріксовані співвідношення між особистісними характеристиками та суб'єктивним благополуччям - від помірних до сильних кореляцій між SWB і ознаками екстраверсії та нейротизму (Costa, McCrae 1980, Tellegen 1985, Headey, Wearing 1992, Watson, Clark 1992).

N. Bradburn and D. Caplovitz (1965) виявили два типи афекту (позитивний і негативний), які раніше вважалися полярними, утворюючи два чинники (ідеться про благополуччя, яке виникає не завжди за повної відсутності негативних чинників).

Узагальнення різних підходів до розуміння суб'єктивного благополуччя дозволило нам виділити декілька ключових тверджень у рамках нашого дослідження а сааме:

1) позитивність виміру благополуччя як наявність різних за інтенсивныстю позитивних показників і переживань;

2) глобальність виміру - взаємозв'язок усіх аспектів життя людини (соціальних, біологічних, психологічних, фрізичних);

3) пролонгованість у часі, динамічність;

4) суб'єктивність як залежність переживання благополуччя від оцінки, відношення і особистого досвіду.

Таким чином, суб'єктивне благополуччя - інтегральне психологічне утворення, що включає оцінку і відношення людини до свого життя і самого себе.

Висновки. На основі аналізу сучасних і класичних досліджень із кожним роком наукове знання про благополуччя суттєво змінюється, ведуться дослідження його джерел і детермінант, уточнюється компонентний склад, термінологічна база, досліджуються особливості впливу різноманітних чинників, таких, як: соціальні відносини, генетична схильність, матеріальний достаток, задоволеність потреб, наявність цілей і сенсу життя, фізична активність, індивідуальні особливості, прийняття себе як особистості тощо.

Перспективи подальших досліджень. Перспективу подальших досліджень убачаємо в продовженні вивчення структурних особливостей моделей і компонентів благополуччя.

\section{Список використаних джерел}

1. Аргайл М. Психология счастья / М. Аргайл. - СПб. : Питер, 2003. - 271 с.

2. Зотова О. Ю. Психологические механизмы формирования субъективного неблагополучия / О. Ю. Зотова // Человеческий капитал. 2015. - № 9 (81) - - C. 107-109.

3. Карапетян Л. В. Теоретические подходы к пониманию субъективного благополучия / Л. В. Карапетян // Известия Уральск. Федеральн. Ун-та. - 2014. - № 1 (123). - С. 171-182. - (Серия "Проблемы образования, науки и культуры").

3. Карсканова С. Стан розробки проблеми психологічного благопопуччя у вітчизняній та закородонній психології / С. Карсканова // Актуальні проблеми практичн. психології : зб. наук. пр. - Херсон: ПП Вишемирський В. С., 2009. - Ч. 1. - С. 477-483

4. Маслоу А. Психология бытия / А. Маслоу. - М.: "Рефл-бук" ; К.: "Ваклер", 1997.

5. Мясищев В.Н. Психология отношений: избранные психологические труды / В. Н. Мясищев. - М.: МПСИ ; Воронеж: МОДЭК, 1995. - 356 с.

6. Шамионов Р. М. Субъективное благополучие личности: психологическая картина и факторы. - Саратов: Изд-во Сарат. ун-та, 2008. - 240 с.

7. Bradburn N. The Structure of Psychological well-being / N. Bradburn. Chicago : Aldine Pub. Co., 1969. - P. 320.

8. Costa P. T. Influence of extraversion and neuroticism on subjective wellbeing : Happy and unhappy people / P. T Costa, R. R. McCrae // Journal of Personality and Social Psychology. - 1980. - № 38. - P. 668-678.

10. Diener E. Cross-cultural correlates of life satisfaction and selfesteeem / E. Diener // Personality and Social Psychology. - 1995. - № 68. -P. 653-663.

А. Халеева, асп.

Киевский национальный университет имени Тараса Шевченко, Киев
11. Diener E. Frequency and intensity : Dimensions underlying positive and negative affect / E. Diener, R. J. Larsen, S. Levine, R. A. Emmons // Journal of Personality and Social Psychology. - 1985. - № 48. - P. 1253-1265.

12. Diener E. Subjective well-being / E. Diener // Psychological Bulletin. 1984. - № 95 (3). - P. 542-575

13. Kerce E. W. "Quality of life : Meaning, measurement, and models" (NPRDCTN-92-15) / E. W. Kerce. - San Diego: Navy Personnel Research and Development Center, 1992 - P 31.

14. Larsen R. J. A multitrait-multimethod examination of affect structure : Hedonic level and emotional intensity / R. J. Larsen, E. Diener // Personality and Individual Differences. - 1985. - № 6. - P. 631-636.

15. Larsen R. J. An evaluation of subjective well-being measures / R. J. Larsen, E. Diener, R. A. Emmons // Social Indicators Research. 1985. - № 17. - P. 1-18.

16. Ryff C. D. Psychological well-being : Meaning, measurement, and implications for psychotherapy research / C. D. Ryff, B. Singer // Psychotherapy and Psychosomatics. - 1996. - № 65. - P. 14-23.

17. Veenhoven R. The utility of happiness / R. M. Ryan, C. Frederick / Social Indicators Research. - 1988. - № 20. - P. 333-354.

18. Watson D. Development and validation of brief measures of positive and negative affect: The PANAS scales / D. Watson, L. A. Clark, A. Tellegen // Journal of Personality and Social Psychology. - 1988. - № 54 (6). - P. 1063-1070

\section{Reference}

1. Arhail M. Psykholohyia schastia / M. Arhail. - SPb. : Pyter, 2003. - $271 \mathrm{~s}$.

2. Zotova O. Yu. Psykholohycheskye mekhanyzmы formyrovanyia subъektyvnoho neblahopoluchyia / O. Yu. Zotova // Chelovecheskyi kapytal. - 2015. - № 9 (81). - S. 107-109.

3. Karapetian L. V. Teoretycheskye podkhodb k ponymanyiu subъektyvnoho blahopoluchyia / L. V. Karapetian // Yzvestyia Uralskoho federalnoho unyversyteta. - 2014. - № 1 (123). - S. 171-182. - (Seryia "Problemb obrazovanyia, nauky y kulturb").

3."Karskanova S. Stan rozrobky problemy psykholohichnoho blahopoluchchia u vitchyznianii ta zakorodonnii psykholohii / S. Karskanova // Aktualni problemy praktychnoi psykholohii : zbirnyk naukovykh prats. Kherson: PP Vyshemyrskyi V. S., 2009. - Ch. 1. - S. 477-483.

4. Maslou A.. Psykholohyia butyia / A. Maslou. - M.: "Refl-buk" - K.: "Vakler", 1997.

5. Miasyshchev V.N. Psykholohyia otnoshenyi: yzbrannыe psykholohycheskye trudы / V. N. Miasyshchev. - M.: MPSY Voronezh: MODЭK, 1995. - $356 \mathrm{~s}$.

6. Shamyonov R.M. Subъektyvnoe blahopoluchye lychnosty: psykholohycheskaia kartyna y faktorb. - Saratov: Yzd-vo Sarat. un-ta, 2008. $-240 \mathrm{~s}$

7. Bradburn N. The Structure of Psychological well-being / N. Bradburn. Chicago : Aldine Pub. Co., 1969. - R. 320.

8. Costa P. T. Influence of extraversion and neuroticism on subjective wellbeing : Happy and unhappy people / P. T. Costa, R. R. McCrae // Journal of Personality and Social Psychology. - 1980 - № 38. - R. 668-678.

10. Diener E. Cross-cultural correlates of life satisfaction and selfesteeem / E. Diener // Personality and Social Psychology. - 1995. - № 68. - P. 653-663.

11. Diener E. Frequency and intensity : Dimensions underlying positive and negative affect / E. Diener, R. J. Larsen, S. Levine and other // Journal of Personality and Social Psychology. - 1985. - № 48. - R. 1253-1265.

12. Diener E. Subjective well-being / E. Diener // Psychological Bulletin. 1984. - № 95 (3). - R. 542-575

13. Kerce E. W. "Quality of life : Meaning, measurement, and models" (NPRDCTN-92-15) / E. W. Kerce. - San Diego: Navy Personnel Research and Development Center, 1992 - P. 31

14. Larsen R. J. A multitrait-multimethod examination of affect structure : Hedonic level and emotional intensity / R. J. Larsen, E. Diener // Personality and Individual Differences. - 1985. - № 6. - R. 631-636.

15. Larsen R. J. An evaluation of subjective well-being measures / R. J. Larsen, E. Diener, R. A. Emmons // Social Indicators Research. 1985. - № 17. - R. 1-18.

16. Ryff C. D. Psychological well-being: Meaning, measurement, and implications for psychotherapy research / C. D. Ryff, B.Singer // Psychotherapy and Psychosomatics. - 1996. - № 65. - P. 14-23.

17. Veenhoven R. The utility of happiness / R. M. Ryan, C. Frederick II Social Indicators Research. - 1988. - № 20. - P. 333-354.

18. Watson D. Development and validation of brief measures of positive and negative affect: The PANAS scales / D. Watson, L. A. Clark, A. Tellegen // Journal of Personality and Social Psychology. - 1988. - № 54 (6). - R. 1063-1070.

Надійшла до редколегії 20.10.18

\section{АНАЛИЗ ОСНОВНЫХ ПОДХОДОВ К ТРАКТОВКЕ СУБЪЕКТИВНОГО БЛАГОПОЛУЧИЯ В ПСИХОЛОГИИ}

Проанализированы основные теории субъективного благополучия, показаны основные различия между теориями, а также взаимосвязь понятий "субъективное благополучие" и "психологическое благополучие". Охарактеризованы основные подходы по выяснению составляющих субъективного благополучия.

Ключевые слова: субъективное благополучие, счастье, удовлетворенность жизнью, психологическое благополучие, качество жизни. 
A. Khaleeva, postgraduate

Taras Shevchenko National University of Kyiv, Kyiv

\section{ANALYSIS OF THE MAIN APPROACHES TO THE TREATMENT OF SUBJECTIVE WELL-BEEING IN PSYCHOLOGY}

The article analyzes the basic theory of subjective well-being. It is indicated that the desire for well-being is one of the main driving forces of human society, its subjective feeling is an important condition for a full-fledged life of a person, therefore, attention is drawn to the need for psychological research related to the analysis of methodological and systemic approaches aimed at studying subjective well-being. The main differences between the theories, as well as the relationship between the concepts of "well-being", "subjective well-being" and "psychological well-being" are shown, a theoretical analysis of existing modern approaches to the problem of studying subjective well-being and its components is carried out. Subjective wellbeing is considered as an integral psychological formation, including the assessment and attitude of a person to his life and himself.

The main approaches to elucidating the components of subjective well-being are characterized-hedonistic and eudemonistic. Based on the analysis of modern and research, a study of its sources and determinants is carried out, the component composition, terminology base is clarified, the influence of various factors, such as: social relations, genetic predisposition, material well-being, joy of needs, existence of goals and meaning of life, physical activity are investigated, individual characteristics, accepting oneself as a person, etc. Through a synthesis of various approaches to understanding subjective well-being, several key statements have been identified in the framework of the study: the positivity of measuring well-being as the presence of positive intensity indicators and experiences of different intensities; global dimension - the interconnection of all aspects of human life (social, biological, psychological, physical) time lag, dynamism; subjectivity as the dependence of the experience of well-being on assessment, attitude and personal experience. Attention is drawn to the fact that the term "subjective well-being" is interdisciplinary and has its meaning in psychology, sociology, economics and the political sciences. The prospect of further research is seen in continuing to study the structural features of models and components of well-being.

Keywords: subjective well-being, happiness, satisfaction with life, psychological well-being, quality of life.

Bulletin of Taras Shevchenko National University of Kyiv.

Series "Psychology". № 2(9), pp. 87-90 (2018)

УдК 27.058.57

DOI: https://doi.org/10.17721/BSP.2018.2(9).22
ISSN 1728-3817

(C) Taras Shevchenko National University of Kyiv,

Publishing Center "Kyiv University", 2018

О. Царькова, д-р психол. наук, доц.,
Г. Варіна, старш. виклад.

Мелітопольський державний педагогічний університет імені Богдана Хмельницького, Мелітополь

\section{ПСИХОЛОГІЧНІ ДЕТЕРМІНАНТИ РЕСОЦІАЛІЗАЦІЇ ЗАСУДЖЕНИХ ЯК ОДИН ІЗ ВАЖЛИВИХ НАПРЯМІВ ПРОФІЛАКТИКИ РЕЦИДИВНОї ЗЛОЧИННОСТІ}

Присвячено аналізу детермінант успішного становлення і функціонування системи ресоціалізації засуджених. Визначено, що одним із найважливіших аспектів повернення осіб, які відбувають покарання, до повноцінного життя в суспільстві $\epsilon$ відтворення у них навичок адаптивної соціальної взаємодїі, у тому числі адекватної сімейної поведінки, корекція сталих і ригідних рольових та поведінкових стереотипів. Сімейні відносини засудженого здебільшого розглядаються як одна з причин його злочинної поведінки та об'єкт ранньої профілактики протиправної поведінки. Серед особливостей сімейних стосунків засуджених виділяється здебільшого така характеристика, як істотне послаблення їх позитивних зв'язків у суспільстві. Проведене дослідження дало змогу дійти висновків, що відновлення соціально-корисних зв'язків та формування адаптивної сімейної поведінки, правового статусу звільненого без надання дієвої допомоги неможливо.

Ключові слова: ресоціалізація, адаптація, поведінкові сценарії, асоціальна поведінка, психологічний захист.

Постановка проблеми. На сучасному етапі розвитку Україна стала на шлях європейської інтеграції, проголосивши пріоритетну цінність прав та свобод людини і взявши на себе обов'язок із їх дотримання. Безперечно, рівень розвитку демократії визначається в державі декількома індикаторами, серед яких важливим $\epsilon$ гуманність ставлення до громадян, які позбавлені волі.

Дослідження показують, що у людей, які перебувають у місцях позбавлення волі протягом тривалого часу, поступово спотворюються поведінкові сценарії, особистісні якості, відбувається втрата навичок адаптивної сімейної взаємодії. Наслідком цього $є$ не тільки велика вірогідність скоєння повторних злочинів, але й збільшення кількості дисфункціональних сімей, що характеризуються сімейним насильством, асоціальними, девіантними формами поведінки їх членів, у тому числі й дітей, маргінальним суспільним статусом, відсутністю умов для особистісного розвитку. Чинники успішного становлення і функціонування ресоціалізації виділяються науковцями за трьома ознаками: соціальноадаптаційними (нормальні стосунки у сім'ї; наявність житла, прописки; постійне місце роботи; корисне проведення дозвілля; підвищення освітнього й культурного рівня; розрив зв'язків зі злочинним світом), змістовнометодичними (зміст і форми педагогічної, психологічної, соціальної й медичної реабілітації), організаційними (наявність команди фрахівців із чітко визначеними задачами, їхня функціональна взаємодія у реасоціалізаційному процесі). Таким чином, одним із найважливіших аспектів повернення осіб, які відбувають покарання, до повноцінного життя в суспільстві $€$ відтворення у них навичок адаптивної соціальної взаємодії, у тому числі адекватної сімейної поведінки, корекція сталих і ригідних рольових та поведінкових стереотипів.

Актуальність зазначеної проблеми визначається суперечністю між потребою в поверненні осіб, які відбувають покарання, до повноцінного життя в суспільстві, необхідністю відтворення у них навичок сімейної взаємодії, а також недостатньою теоретичною, методологічною й методичною розробленістю цієї проблеми.

Аналіз стану розробленості проблеми в спеціальній літературі. По закінченні терміну покарання засуджений знову потрапляє до суспільства, норм і законів якого він має дотримуватися, але не завжди у змозі їм виконувати через специфічні особистісні особливості й виражену соціальну дезадаптованість. Саме тому на перший план у роботі закладів, що виконують кримінальні покарання, виступає проблема ресоціалізації засуджених. Хоча ця проблема і знайшла певне відображення в наукових публікаціях Ю. М. Антоняна,Ю.А.Алферова, В. І. Дробишева, А. І. Зубкова, С. А. Лузгіна, А. В. Піщелко, В.М.Позднякова, М. П. Стурової, В. Е. Южаніна й інших авторів, на сьогодні вона є недостатньо вирішеною [6]. У нашій статті ми розглядаємо психологічний аспект ресоціалізації, який отримав теоретичну й експериментальну розробку в дослідженнях Ю. М. Антоняна,

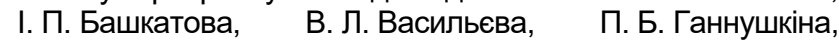
М.Н.Гернета, А. Д. Глоточкина, В. Г. Дєєва, М. І. Єнікєєва, Ю. В. Жульової, А. Ф. Зелінського, А. Г. Ковальова, В. Н. Кудрявцева, А. Ф. Лазурського, А. С. Макаренка, А.ІІ. Панкіна, В. Ф. Пиріжкова, А. Н. Сухова, А. І. Ушатікова тощо. [3]. У роботах визначається поняття "ресоціализація", мета, задачі, напрями, принципи і методи цього процесу, досліджуються психологічні особливості особистості засудженого.

(С) Царькова О., Варіна Г., 2018 